\title{
DETOKSIKASI AIR BUANGAN YANG MENGANDUNG PESTISIDA
}

\author{
Oleh : Ir. Siti Noer Tri Hidayati *)
}

\begin{abstract}
Detoxication is the transformation of a toxic substance into a less toxic product. Detoxication of the pesticide contaminated waste water can be done by biota and abiota. Detoxication by biota may involve one or more the following reactions : oxidations, dechlorinations, reductions, hydrolysis, aromatic ring cleavage, etc. Detoxication by abiota may involved physical and chemical treatment. Three types of pesticide contaminated waste water were prepared in theis experiment. The first type contain MIPC, the second Carbofuran and the other BPMC. The concentration of each type are carried out after $1,2,3$, and 4 weeks. The result indicate that the longer detoxication time is better result, the kind of toxicants affected detoxication product, $\mathrm{KOH}$ is stronger than $\mathrm{NaOH}$.
\end{abstract}

\section{PENDAHULUAN}

Dalam pertanian pestisida telah menjadi bagian yang penting sekali, sehingga penggunaannya cenderung meningkat baik jumlah maupun jenisnya. Akan tetapi dibalik kelebihannya pestisida banyak mempunyai kelemahan dan menimbulkan pengaruh samping yang tidak diinginkan. Penggunaan pestisida yang kurang bijaksana justru akan mengakibatkan bahaya yang tidak diinginkan dikemudian hari.'

Banyak jenis pestisida yang bila dipergunakan cepat rusak terutama bila dipergunakan di daerah tropis. Organoklor merupakan jenis yang stabil, efektif dan toksisitas akutnya relatif rendah, tetapi jenis ini mempunyai sifat akumulatif dan residu yang lama, sehingga dapat membahayakan. Pestisida jenis organofosfat mempunyai sifat lebih efektif, tetapi toksisitas akutnya pada manusia ternyata lebih tinggi dari organoklor. Jenis karbamat sifat biologisnya serupa dengan jenis organofosfat.

Pestisida-pestisida tersebut di atas mempunyai daya aktifitas yang kuat, persisten dan sebagai racun perut bila tertelan. Di samping itu dapat menyebabkan kerusakan pada komponen-komponen selubung sel saraf sehingga fungsi sel saraf terganggu. Kerusakan pada komponen sel saraf ini dapat menyebabkan kematian atau kelainan pada susunan saraf.

Berbagai jenis pestisida dapat masuk ke sungai, danau dan laut melalui berbagai jalan. Pestisida yang digunakan, banyak dịantaranya yang relatif stabil dan meninggalkan residu dalam tanah atau di atmosfir dan selanjutnya dapat berpindah ke sistem perairan. Di dalam sistem perairan, pestisida mengalami peruraian menjadi senyawa yang lebih sederhana dan tetap tinggal atau menguap ke udara.

Mengingat pentingnya masalah-masalah yang ditimbulkan sebagai akibat penggunaan pestisida, maka penelitian detoksikasi air buangan yang mengandung pestisida sangat perlu, di samping pengawasan yang intensif terhadap pengaruh penggunaan pestisida terhadap lingkungan.

*) Staf Bałai Penelitian Pupuk dan Petrokimia, Balai Besar Industri Kimia. 


\section{KARAKTERISTIK PESTISIDA YANG MENYEBABKAN PENCEMARAN.}

Bermacam-macam senyawa kimia dengan struktur dan sifat yang berbeda telah digunakan sebagai pestisida. Dari senyawa anorganik yang sederhana seperti timbal arsenat dan tembaga sulfat, sampai campuran komplek dari molekul-molekul organik.

Kestabilan dan persistensi pestisida dalam sistem perairan merupakan fungsi dari struktur kimianya. Kestabilan pestisida bervariasi mulai dari yang tidak stabil dan terpecah dalam beberapa jam sampai senyawa yang sangat stabil dan dapat tahan selama beberapa tahun. Persistensi pestisida di dalam sistem perairan yang terbesar adalah insektisida organoklor, menengah untuk organofosfat dan insektisida karbamat dan yang terkecil untuk herbisida.

Tingkat kelarutan pestisida dalam air merupakan suatu sifat yang dapat menambah atau mengurangi kemampuan pestisida sebagai pencemar pada sistem perairan. Kelarutan beberapa pestisida dalam air dapat dilihat pada Tabel 1. Bila suatu pestisida mudah larut, maka pestisida yang berasal dari Lahan pertanian akan mudah pula mengalir masuk ke sistem perairan dan menyebar ke seluruh sistem tersebut.

Tabel 1. Kelarutan pestisida dalam air.

\begin{tabular}{|l|c|}
\hline \multicolumn{1}{|c|}{ Pestisida } & Kelarutan dalam air (ppm) \\
\hline Organoklorin: & \\
- D.D.T. & 0,0012 \\
- Aldrin & 0,01 \\
- Endrin & 0,23 \\
Organofosfat: & \\
- Diazinon & 40 \\
- Malation & 145 \\
Karbamat: & \\
- Karbaril & 40 \\
- Karbofuran & 700 \\
\hline
\end{tabular}

Sumber : Pesticides in Aquatic Environments.

Tetapi makin mudah kelarutan suatu pestisida, cenderung tidak tahan lama dalam air dan lebih mudah diencerkan. Kelebihan dari pestisida yang tidak larut, tidak segera mengalami proses pelarutan dalam sistem perairan dan sekali berada dalam sistem perairan, secara cepat berikatan dengan organisme hidup atau mati, atau merupakan bagian dari endapan dasar. Oleh sebab itu hanya berpengaruh pada biota bila senyawa tersebut sangat beracun, mengumpul pada jaringan organisme atau berikatan dengan senyawa organik yang merupakan makanan dari organisme yang lain.

Tingkat peracunan yang tinggi pada binatang dan tumbuh-tumbuhan air merupakan suatu batasan yang penting untuk menentukan apakah pestisida merupakan suatu pencemar dalam sistem perairan. 


\section{DETOKSIKASI AIR BUANGAN YANG MENGANDUNG PESTISIDA.}

Sistem perairan mulai tercemar oleh pestisida karena pemakaian yang berlebihan atau secara tidak disengaja. Hal yang terakhir merupakan yang sering terjadi. Pencemaran yang tidak disengaja terjadi karena penyemprotan, pengendapan, pengaliran dan pelepasan bila sejumlah besar air buangan industri memasuki badan air atau bila sisa-sisa pestisida atau wadah pestisida dibuang kebadan air. Tanda-tanda bahwa suatu sistem perairan telah tercemar oleh pestisida dapat diketahui dari adanya fluktuasi residu pestisida di dalam air atau dasar endapan.

Penanganan air buangan industri ada bermacam-macam, mulai dari tanpa pengolahan sampai pengolahan dengan sistem detoksikasi yang canggih.

Detoksikasi adalah perubahan dari bahan yang bersifat beracun menjadi bahan yang kurang/tidak beracun. Proses detoksikasi dapat dilakukan oleh biota dan abiota.

\section{A. DETOKSIKASI OLEH BIOTA.}

Pestisida yang dipergunakan di areal pertanian, perkebunan atau diperumahan untuk membasmi nyamuk dan serangan-serangan lainnya, pengaruhnya akan tersebar kemedia-media lain, terutama pada air, tanah dan organisme yang terdapat di alam. Di alam pestisida diserap oleh berbagai komponen lingkungan, kemudian terangkut ketempat lain oleh air, angin atau berbagai organisme.

Mikroorganisme dapat memecah beberapa senyawa kimia dari yang sederhana seperti polisakarida, asam amino dan lain-lain sampai yang sangat kompleks seperti tanaman, minyak bumi, karet dan yang lain.

Detoksikasi pestisida oleh biota dapat disertai oleh satu atau lebih reaksi berikut: oksidasi, hidrolisa, dealkilasi, deklorinasi, reduksi, pemecahan cincin aromatik dan lain-lain.

1. Reaksi Oksidasi.

Oksidasi pestisida dapat disertai dengan penempatan fenol atau hidrolisa alkohol kedalam hidrokarbon, oksidasi dari alkohol menjadi keton atau asam karboksilat, oksidasi alkil, pembentukan epoksi, N-oksidasi dan oksidasi dehidroklorinasi dari foto isomer siklodiena. Reaksi yang terjadi pada detoksikasi pestisida dapat dilihat pada Tabel 2. 
Tabel 2. Beberapa contoh reaksi oksidasi pada detoksikasi pestisida oleh biota.

\begin{tabular}{|c|c|c|c|}
\hline \multirow{2}{*}{ Detoksikasi } & \multicolumn{3}{|c|}{ Pestisida yang terdetoksikasi oleh } \\
\hline & Mikroorganisme & Tumbuh ${ }^{2}$ an & Binatang \\
\hline - Aril hidroksilasi & Karbaril & Karbaril,2,D. & Karbaril, Baygon. \\
\hline - Alifatik hidroksilasi. & Aldehid, keton & Aldrin & Siklodiena, DDT \\
\hline - O - dealkilasi & - & Malation, Abate. & Malation, paration \\
\hline - N-dealkilasi & Karbaril, Simazin. & Fenilurea, Triazin. & $\begin{array}{l}\text { N-metil dan } \\
\text { N,N dimetil }\end{array}$ \\
\hline - N - metil hidroksilasi. & - & Bidrin, Azodrin. & $\begin{array}{l}\text { N-metil karbamat, } \\
\text { Bidrin. }\end{array}$ \\
\hline - Sulfooksidasi & Temik, Fenitrotion. & Temik, Abate & Temik \\
\hline
\end{tabular}

Sumber : Environmental Dynamics of Pesticides.

\section{2., Reaksi Deklorinasi}

Proses deklorinasi menjadi sangat penting dalam detoksikasi karena beberapa pestisida merupakan hidrokarbon teklorinasi.

Tabel 3. Beberapa contoh pestisida yang mengalami reaksi deklorinasi di dalam biota.

\begin{tabular}{|l|l|l|l|}
\hline \multirow{2}{*}{ Detoksikasi } & \multicolumn{3}{|c|}{ Pestisida yang termetabolisme dalam } \\
\cline { 2 - 4 } & Mikroorganisme & Tumbuh ${ }^{2}$ an & \multicolumn{1}{c|}{ Binatang } \\
\hline $\begin{array}{l}\text { Deklorinasi } \\
\text { - Reduksi }\end{array}$ & & & \\
- Oksidasi & D.D.T. & J BHC & DDT, \& BHG \\
Dehidroklorinasi & 2,4 D & 2,4 D. 2,4,5T & Siklodiena \\
- Anaerob & D.D.T. & - & D.D.T. \\
- Oksidasi & - & - & Fotodieldrin \\
\hline
\end{tabular}

Sumber : Environmental Dynamics of Pesticides.

a. Deklorinasi dan dehidroklorinasi.

DDT akan mengalami proses deklorinasi dan dehidroklorinasi secara anaerob menjadi DDD oleh mikroorganisme tanah, binatang dan juga tumbuh-tumbuhan. 

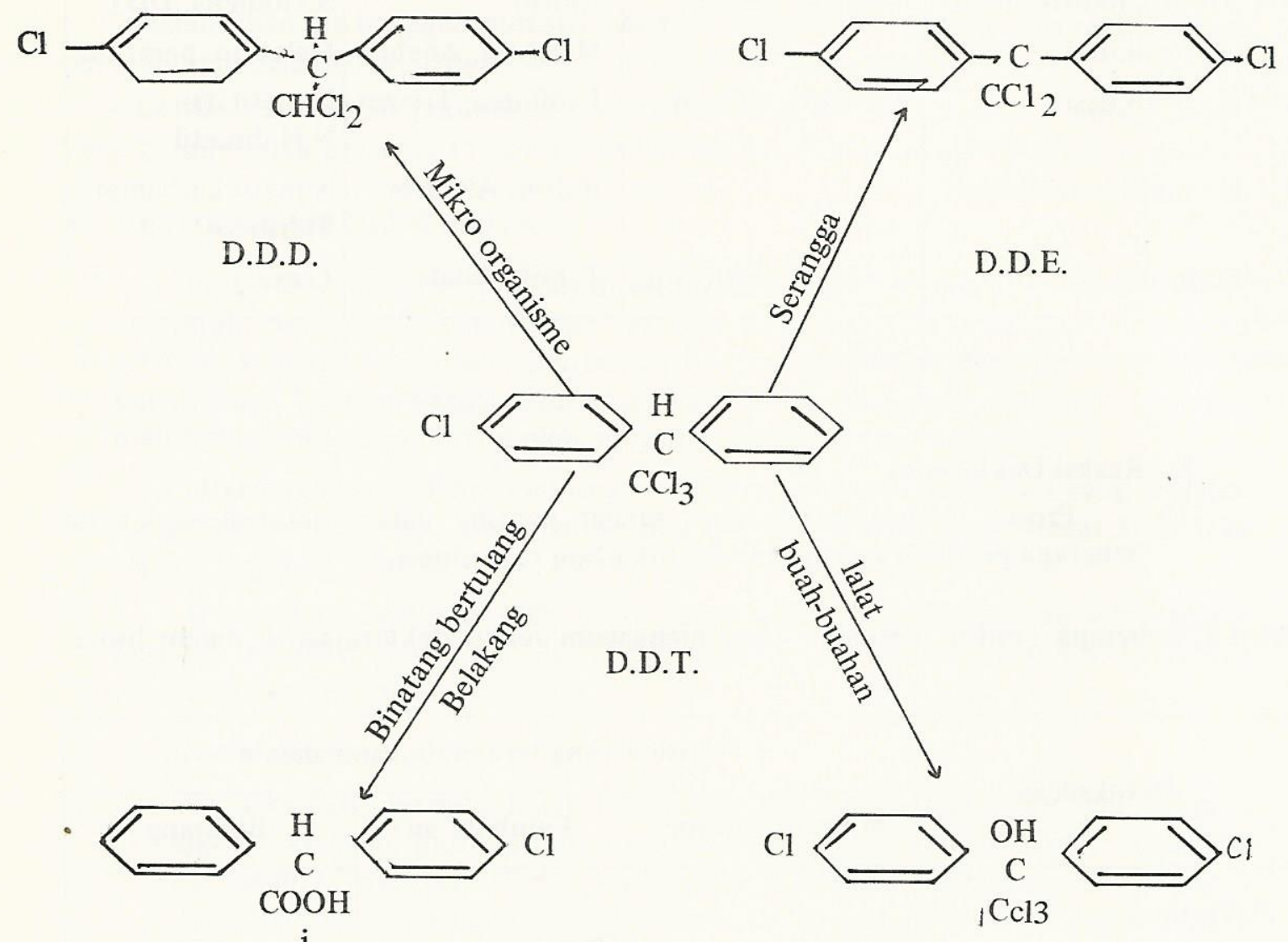

$\mathrm{COOH}$

$\mathrm{i}$
$-\mathrm{C}-$
O
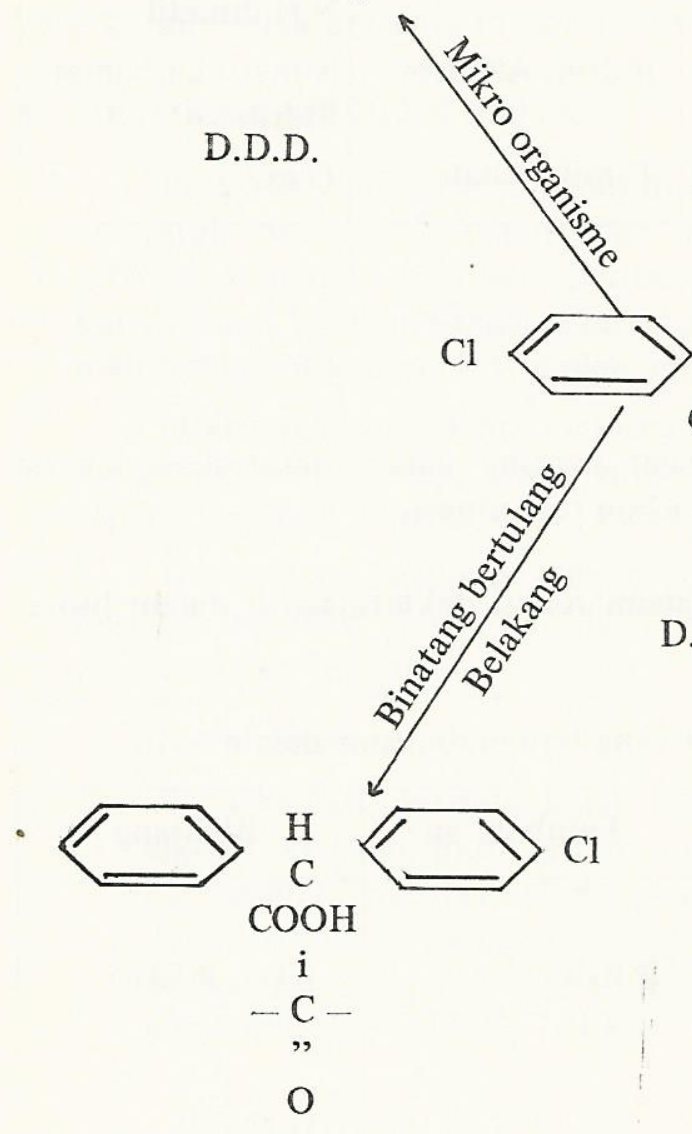

Diklorobenzofenan (DBP)

Proses dehidroklorinasi anarob dari DDT menjadi DDE sering terjadi pada serangga dan serangga tanah. DDD dan ortokloro DDT dapat juga terhidroklorinasi BHC terklorinasi oleh mikroorganisme menjadi BTC dan pentaklorosikloheksana.

b. Oksidasi dehidroklorinasi

Aldrin dan Dieldrin terurai oleh sinar matahari menjadi foto aldrin dan foto dieldrin, ini terjadi pada lalat, nyamuk dan tikus, selanjutnya akan mengalami deklorinasí menjadi foto dieldrin keton.

\section{Reaksi Reduksi}


Tabel 4. Contoh beberapa pestisida yang mengalami reaksi reduksi.

\begin{tabular}{|l|l|}
\hline \multicolumn{1}{|c|}{ Organisme } & \multicolumn{1}{|c|}{ Pestisida yang termetabolisme } \\
\hline $\begin{array}{l}\text { - Mikroorganisme } \\
\text { - Tumbuh-tumbuhan } \\
\text { - Binatang }\end{array}$ & EPN, Denitrotion \\
& Triferalin, Nitrofen \\
& Paration, EPN. \\
\hline
\end{tabular}

Bakteri (Arthrobacter simplex dan Pseudomonas sp) mereduksi $\mathrm{NO}_{2}$ menjadi $\mathrm{NH}_{2}$ dan menggantikannya dengan $\mathrm{OH}$ pada 3,5 dinitro ortokresol, 2 - nitrofenol dan 4 - nitrofenol.

\section{Reaksi Hidrolisa}

Selain oksidasi, hidrolisa merupakan mekanisme detoksikasi yang sangat penting, khususnya sejak sebagian besar pestisida merupakan senyawa ester dan amida. Senyawa ester dan amida sangat mudah terhidrolisa oleh mikroorganisme, tumbuh-tumbuhan dan binatang. Contoh dari beberapa pestisida yang terhidrolisa oleh beberapa mikroorganisme dapat dilihat pada Tabel 5 .

Tabel 5. Contoh dari beberapa pestisida yang terhidrolisa oleh beberapa mikroorganisme.

\begin{tabular}{|l|l|}
\hline \multicolumn{1}{|c|}{ Pestisida } & \multicolumn{1}{|c|}{ Mikroorganisme } \\
\hline DFP dan beberapa organofosfat & Pseudomonas melaphora \\
Malation & Trichoderma viride \\
Sumition & Bacillus subtilis \\
Karbaril & Mikroorganisme tanah \\
Diazinon & Mikroorganisme tanah \\
\hline
\end{tabular}

Tumbuh-tumbuhan dapat menghidrolisa 2,4 D menjadi beberapa derivatnya, termasuk dikloroanisol. Tumbuh-tumbuhan juga dapat menghidrolisa insektisida organofosfat dan fungisida, sebagai contoh : malation dirubah menjadi dimetilditiofosfat, dimetil fosforotiolat malation mono dan diacid.

Organofosfat dan insektisida ester karbamat sangat cepat dihidrolisa oleh serangga dan binatang bertulang belakang.

Amida terhidrolisa sangat cepat oleh tumbuh-tumbuhan dan binatang. Propanil sangat cepat dirubah menjadi 2,4 dikloroanilin di dalam tanaman padi-padian. 


\section{Reaksi Pemecahan Cincin.}

Cincin benzen di dalam pestisida seperti 2,4 D dan DDT mengalami pemecahan orto atau meta oleh mikroorganisme.

Simazin dapat juga mengalami pemecahan cincin secara lambat oleh mikroorganisme tanah.

Proses detoksikasi oleh organisme hidup disertai oleh satu atau lebih reaksi. Perbedaan organisme satu dengan yang lain terutama terletak pada kecepatan detoksikasi yang terjadi. Perbedaan kualitatif pada biotransformasi akan menentukan secara selektif toksisitas dari pestisida, sebagai contoh ester dan amida dapat dipecah pada beberapa tempat oleh lebih dari satu enzim detoksikasi. Perbedaan aktifitas dari enzim di dalam beberapa biota dapat menentukan toksisitas untuk organisme sasaran dan bukan sasaran.

Malation dipecah oleh beberapa enzim yaitu karboksiestarase, fostatase, dimetilase dan campuran oksidasi. Malation cepat terurai oleh biota karena dipecah oleh beberapa enzim, sehingga dengan demikian tidak lama berada dilingkungan.

Herbisida 2,4 D terdetoksikasi dengan cara hidrolisa, hidroksimetilasi, deklorinasi, dekarbosiklasi dan pemecahan cincin. Tumbuh-tumbuhan merubahnya menjadi dikloroanisol, ester dan eter. Bakteri Pseudomonas vulgaris $s p$. merubahnya menjadi 2,4 diklorofenol, monoklorofenol, fenol, klorohidroquionon, klorokatekol dan beberapa hasil metabolisme. Diklorokatekol dapat mengalami pemecahan cincin dan menghasilkan $\alpha$ dan $\beta$ asam koloromukonik yang selanjutnya dapat mengalami deklorinasi.

Insektisida organoklor seperti DDT cepat mengalami deklorinasi pada beberapa serangga. Beberapa serangga seperti lalat rumah, lalat buah-buahan Drosophila melanogaster mengoksidasinya menjadi keltan dan hasil metabolisme yang larut dalam air.

Mamalia dapat mengubah DDT menjadi DDE, DDA, diklorobenzofenan, diklorobenzilhidrol, DDD dan diklorofeniletan. Beberapa bakteri memecah DDT menjadi karbondioksida $\left(\mathrm{CO}_{2}\right)$.

\section{B. DETOKSIKASI OLEH ABIOTA.}

Pengurangan toksisitas (detoksikasi) air buangan yang mengandung pestisida, selain dilakukan oleh biota, juga dilakukan oleh abiota Detoksikasi oleh abiota meliputi:

\section{Pengolahan secara fisika.}

Pengolahan secara fisika dilakukan dengan beberapa cara yaitu:

a. Proses penyaringan.

Bahan yang mengandung pestisida disaring sehingga partikel yang besar dapat terpisah dari partikel yang kecil. Biasanya penyaringan ini dilakukan dengan cara melewatkan air buangan yang mengandung pestisida pada saringan pasir. 
b. Proses pengendapan.

Dilakukan dengan cara menambahkan suatu bahan yang mempunyai sifat selektif, sehingga bahan yang tidak dikehendaki (beracun) dapat dipisahkan.

c. Proses pengenceran.

Proses pengenceran ini dimaksudkan supaya konsentrasi bahan beracun menjadi kecil sehingga sifat racun dari bahan menjadi berkurang.

d. Proses penggumpalan.

Dilakukan dengan cara menambahkan suatu bahan yang dapat mengumpulkan bahan yang beracun dan selanjutnya bahan tersebut dipisahkan dari yang lain.

e. Proses penyerapan.

Proses penyerapan ini ada 2 macam, yaitu: proses penyerapan pada seluruh bagian dari zat (absorpsi) dan proses penyerapan pada permukaan zat (adsorpsi). Proses penyerapan dilakukan dengan cara menambahkan bahan yang mampu menyerap bahan yang dikehendaki sehingga mudah dipisahkan dari yang lain.

Pengolahan air buangan dengan proses penggumpalan, pengendapan dan penyaringan dapat menghilangkan $80-90 \%$ DDT yang ada di dalam air buangan dengan konsentrasi $0,1-10 \mathrm{ppm}$.

Pengujian efektifitas dari proses penyaringan untuk menghilangkan dieldrin, endrin, lindan dan DDT di dalam air pada pengolahan konvensional yang menggunakan proses penggumpalan yang diikuti penyaringan dengan pasir menunjukkan hasil yang efektif. Hasil yang dicapai hampir semua DDT (10 ppm x 10 ${ }^{3}$ ) dapat dihilangkan dan kurang dari $20 \%$ untuk Lindan yang dapat dihilangkan.

Penggunaan karbon aktif dapat menghilangkan DDT di dalam air, tetapi untuk BHC dengan konsentrasi yang rendah dan Toxafen tidak berhasil baik. Penghilangan Lindan dari 10 ppm x $10^{6}$ menjadi $1 \mathrm{ppm} \times$ $10^{6}$ memerlukan arang aktif sebanyak $29 \mathrm{ppm}$.

\section{Pengolahan secara kimia.}

a. Proses Oksidasi.

Untuk menghilangkan pestisida pada air buangan biasanya dilakukan dengan menggunakan ozon, peroksida atau aerasi. Penghilangan Lindan pada air dengan mempergunakan ozon memberikan hasil yang baik.

b. Pengaturan PH.

Dilakukan dengan cara menambahkan suatu asam atau basa sehingga bahan yang beracun dapat/mudah dipisahkan/dihilangkan.

c. Proses reduksi

Proses reduksi dilakukan dengan menambahkan reduktor pada air 
buangan yang mengandung pestisida sehingga senyawa racun menjadi tidak beracun.

d. Proses hidrolisa.

Dilakukan dengan cara menambahkan suatu alkali, biasanya dipergunakan alkali kuat, sehingga bahan yang beracun akan terurai menjadi bahan yang tidak beracun.

Fenitrotion akan terhidrolisa sebanyak $50 \%$ pada suhu $30^{\circ} \mathrm{C}$ dengan larutan $\mathrm{NaOH} 0,01 \mathrm{~N}$ selama 270 menit dan memerlukan waktu 12 menit jika larutan yang dipergunakan $\mathrm{NaOH} 0,1 \mathrm{~N}$.

Hidrolisa dari pestisida Karbamat dengan melewatkannya melalui suatu kolom yang berisi resin dan alkali kuat memberikan hasil seperti pada Tabel 6.

Tabel 6. Kecepatan hidrolisa dari Karbofuran $(30 \mathrm{ppb})$ pada $15^{\circ} \mathrm{C}$.

\begin{tabular}{|c|c|c|c|}
\hline $\begin{array}{l}\text { Konsentrasi } \\
\mathrm{NaOH} \times 10^{3} \\
(\text { mol liter }\end{array}$ & $\begin{array}{c}\text { Konstanta } \\
\text { Kecepatan order satu } \\
\text { K obs } x 10 \\
\left(\min ^{-1}\right)\end{array}$ & $\begin{array}{c}\text { Kecepatan } \\
\mathbf{r}^{2} \\
(\%)\end{array}$ & $\begin{array}{c}\text { Konstanta } \\
\text { Kecepatan order dua } \\
\mathrm{k} \mathrm{r} \\
\text { (liter min mol }{ }^{-1} \text { ) }\end{array}$ \\
\hline 3,73 & 1,16 & 99,8 & 31,1 \\
\hline 5,59 & 1,67 & 99,8 & 29,9 \\
\hline 6,51 & 1,95 & 99,8 & 30,0 \\
\hline 8,14 & 2,58 & 100 & 31,7 \\
\hline 9,77 & 2,95 & 99,5 & 30,2 \\
\hline
\end{tabular}

Sumber : Treatment and Disposal of Pesticide Waste.

\section{METODA PENELITIAN.}

\section{A. BAHAN DAN PERALATAN.}

Bahan yang dipergunakan dalam penelitian ini adalah bahan aktif pestisida, $\mathrm{NaOH}$ dan $\mathrm{KOH}$.

1. Bahan aktif pestisida

a. BPMC dan MIPC, yang diperoleh dari produsen bahan aktif pestisida di Surabaya.

b. Karbofuran, yang diperoleh dari formulator pestisida di Semarang.

2. Larutan $\mathrm{NaOH} 0,01 \mathrm{~N}$ dan $\mathrm{KOH} 0,01 \mathrm{~N}$ sebagai pelarut.

Peralatan yang dipergunakan adalah HPLC, neraca analitik labu takar dan peralatan gelas lainnya untuk keperluan analisa. 


\section{B. PROSEDUR PENELITIAN}

Dalam penelitian ini dilakukan analisa kadar bahan aktif pestisida pada suatu larutan yang akan mengalami proses detoksikasi. Konsentrasi bahan aktif pada larutan dibuat atas 4 level yaitu $5,10,15$ dan $20 \mathrm{ppm}$.

Waktu proses detoksikasi dilakukan selama 1, 2, 3 dan 4 minggu. Analisa kadar bahan aktif dilakukan dengan menggunakan HPLC.

\section{KRITERIA DAN PENGUKURAN.}

Dalam penelitian ini akan diteliti pengaruh dari waktu, konsentrasi dan pelarut terhadap kestabilan bahan aktif pestisida.

Kriteria yang dipergunakan untuk mengukur pengaruh tersebut adalah pengurangan kadar bahan aktif pestisida setelah proses detoksikasi. Pengurangan kadar bahan aktif dihitung sebagai berikut :

$\frac{\text { Kadar bahan aktif setelah detoksikasi }}{\text { Kadar bahan aktif sebelum detoksikasi }} \times 100 \%$

\section{RANCANGAN PERCOBAAN.}

Penelitian ini dilakukan menurut Rancangan Acak Lengkap secara faktorial. Faktor yang diteliti pengaruhnya adalah jenis bahan aktif, jenis pelarut, konsentrasi bahan aktif dan waktu proses detoksikasi.

Faktor bahan aktif terdiri dari 3 level yaitu: MIPC, BPMC, dan Karbofuran. Faktor pelarut terdiri dari 2 level yaitu larutan $\mathrm{NaOH} 0,01 \mathrm{~N}$ dan $\mathrm{KOH} 0,01 \mathrm{~N}$. Konsentrasi bahan aktif terdiri dari 4 level yaitu 5 ppm, 10 ppm, 15 ppm dan 20 ppm. Waktu proses detoksikasi terdiri dari 4 level yaitu 1, 2, 3 dan 4 minggu. Ulangan dilakukan 2 kali.

\section{HASIL DAN PEMBAHASAN.}

Dari hasil analisa statistik diperoleh daftar sidik ragam seperti pada Tabel 7.

Dari hasil analisa keragamannya, ternyata bahwa waktu proses $1,2,3$ dan 4 minggu menunjukkan perbedaan sangat nyata. Hal ini jelas karena makin lama waktu yang dibutuhkan untuk proses detoksikasi makin sempurna kontak antara pelarut dengan bahan aktif pestisida tersebut. Antara perlakuan yang menggunakan bahan aktif BPMC, MIPC dan Karbofuran menunjukkan perbedaan yang sangat nyata. Ini dapat dimengerti sebab setiap jenis bahan aktif berlainan, walaupun bahan aktif tersebut masih termasuk dalam satu golongan. Demikian pula dengan perlakuan yang menggunakan konsentrasi yang berbeda, memberikan perbedaan yang sangat nyata.

Interaksi antara waktu proses dan penggunaan bahan aktif menunjukkan perbedaan yang nyata. Hal ini berarti bahwa di samping waktu kontak, struktur kimia dari bahan aktif juga memberi pengaruh yang sangat nyata pada proses detoksikasi.

Interaksi antara waktu proses dan konsentrasi bahan aktif menunjukkan perbedaan yang nyata. Hal ini menunjukkan bahwa selain waktu, konsentrasi bahan aktif juga memberikan pengaruh pada proses detoksikasi tersebut. 
Tabel 7. Daftar sidik ragam kadar bahan aktif yang hilang $(\%)$ (dengan pelarut/pereaksi $\mathrm{NaOH} 0,01 \mathrm{~N}$ ).

\begin{tabular}{|c|r|r|r|r|r|r|}
\hline $\begin{array}{c}\text { Sumber } \\
\text { Keragaman }\end{array}$ & $\begin{array}{c}\text { Derajat } \\
\text { Bebas }\end{array}$ & $\begin{array}{c}\text { Jumlah } \\
\text { Kwadrat }\end{array}$ & $\begin{array}{c}\text { Kumadrat } \\
\text { Tengah }\end{array}$ & \multicolumn{2}{|c|}{$F_{\text {Hitung }}$} & \multicolumn{2}{|c|}{$F_{\text {Tabel }}$} \\
\hline Perlakuan & 47 & $95.549,08$ & $2.032,96$ & $7.010,21 * *$ & 1,61 & 1,97 \\
A & 3 & $54.420,03$ & $18.140,01$ & $62.551,76^{* *}$ & 2,80 & 4,29 \\
B & 2 & $27.921,07$ & $13.960,54$ & $48.139,79 * *$ & 3,19 & 5,08 \\
C & 3 & 198,79 & 66,26 & $228,48 * *$ & 2,80 & 4,29 \\
AB & 6 & $9.011,67$ & $1.501,95$ & $5.179,14 * *$ & 2,38 & 3,20 \\
AC & 9 & 652,75 & 72,53 & $250,10^{* *}$ & 2,07 & 2,79 \\
BC & 6 & $1.305,46$ & 217,58 & $750,28 * *$ & 2,38 & 3,20 \\
ABC & 18 & $2.039,31$ & 113,295 & $390,67 * *$ & 1,84 & 2,28 \\
Sisa & 48 & 13,93 & 0,29 & & & \\
\hline Total & 95 & $95.563,01$ & & & & \\
\hline
\end{tabular}

** Sangat hyata dengan selang kepercayaan : 99\%

$$
\text { Keterangan : } \begin{aligned}
\mathrm{A} & =\text { Waktu proses } \\
\mathrm{B} & =\text { Jenis bahan aktif } \\
\mathrm{C} & =\text { Konsentrasi bahan aktif. }
\end{aligned}
$$

Interaksi antara jenis bahan aktif dan konsentrasi bahan aktif juga menunjukkan perbedaan yang nyata, berarti baik jenis bahan aktif maupun konsentrasi keduanya memberi pengaruh yang sangat besar pada proses detoksikasi.

Interaksi tiga faktor antara waktu proses, jenis bahan aktif, dan konsenterasi bahan aktif juga menunjukkan perbedaan yang sangat nyata. Hal ini jelas sebab masing-masing faktor baik waktu proses, jenis bahan aktif maupun konsentrasi bahan aktif memberikan pengaruh pada proses detoksikasi tersebut.

Dari Tabel 8 dapat dilihat bahwa hasil analisa keragamannya ternyata memberikan hasil sebagai berikut: pengaruh perlakuan kedua jenis pelarut menunjukkan perbedaan yang nyata, hal ini disebabkan karena masing-masing pelarut mempunyai daya aktifitas yang berlainan walaupun keduanya termasuk alkali keras. Pelarut $\mathrm{KOH}$ ternyata memberikan hasil detoksikasi yang lebih baik dari pada pelarut $\mathrm{NaOH}$. $\mathrm{Hal}$ ini berarti $\mathrm{KOH}$ lebih kuat dan dari pada $\mathrm{NaOH}$ (sesuai dengan deret volta) ini disebabkan karena diameter dari $\mathrm{KOH}$ lebih besar dari $\mathrm{NaOH}$ sehingga mudah melepaskan ion-ionnya untuk bereaksi. Interaksi antara jenis pelarut dan waktu memberikan perbedaan yang nyata, juga interaksi antara waktu dan konsentrasi, interaksi antara jenis pelarut dan konsentrasi bahan aktif. Interaksi ke 3 faktori waktu, jenis pelarut dan konsentrasi menunjukkan perbedaan yang sangat nyata. Hal ini disebabkan masing-masing faktor memberikan pengaruh yang besar pada proses detoksikasi tersebut. 
Tabel 8. Daftar sidik ragam kadar bahan aktif yang hilang (\%) (Bahan Aktif MIPC).

\begin{tabular}{|c|r|r|r|r|r|r|}
\hline $\begin{array}{c}\text { Sumber } \\
\text { Keragaman }\end{array}$ & $\begin{array}{c}\text { Derajat } \\
\text { Bebas }\end{array}$ & $\begin{array}{c}\text { Jumlah } \\
\text { Kwadrat }\end{array}$ & $\begin{array}{c}\text { Kwadrat } \\
\text { Tengah }\end{array}$ & F Hitung & \multicolumn{2}{|c|}{ Tabel } \\
\cline { 3 - 7 } & 31 & $69.610,44$ & $2.245,50$ & $7.017,19 * *$ & 1,81 & 2,30 \\
Perlakuan & 1 & 585,88 & 585,88 & $1.830,88 * *$ & 4,17 & 7,56 \\
P & 3 & $35.080,55$ & $11.693,52$ & $36.542,25 * *$ & 2,92 & 4,51 \\
A & 3 & $1.141,86$ & 380,62 & $1.189,44 * *$ & 2,92 & 4,51 \\
C & 3 & $13.795,70$ & $4.598,57$ & $14.370,53 * *$ & 2,92 & 4,51 \\
P A & 3 & $2.364,12$ & 788,04 & $2.462,63 * *$ & 2,21 & 3,07 \\
P C & 9 & $8.762,91$ & 973,66 & $3.042,69 * *$ & 2,21 & 3,07 \\
A C & 9 & $7.879,42$ & 875,49 & $2.735,91 * *$ & 2,21 & 3,07 \\
PAC & 32 & 10,28 & 0,32 & & & \\
Sisa & 63 & $69.620,72$ & & & & \\
\hline Total & 63 & & & & & \\
\hline
\end{tabular}

** Sangat nyata dengan selang kepercayaan : 99\%

Keterangan : $\mathrm{P}=$ Jenis pelarut
$\mathrm{A}=$ Waktu proses
$\mathrm{C}=$ Konsentrasi bahan aktif

\section{KESIMPULAN DAN SARAN.}

1. Lamanya detoksikasi sangat mempengaruhi hasil dari proses detoksikasi, yaitu makin lama waktu yang dipergunakan makin lama waktu kontak antara bahan aktif dengan pelarut sehingga hasil detoksikasi makin baik.

2. Jenis bahan aktif pestisida mempengaruhi hasil detoksikasi sebab setiap bahan aktif mempunyai struktur kimia yang spesifik.

3. Jenis pelarut/pereaksi yang dipergunakan untuk proses detoksikasi mempengaruhi hasil detoksikasi, sebab masing-masing pereaksi mempunyai daya aktifitas yang berlainan. Pelarut/pereaksi KOH lebih kuat dari pada pelarut/pereaksi $\mathrm{NaOH}$.

Mengingat hal-hal tersebut di atas maka perlu dilakukan penelitian lebih lanjut mengenai proses detoksikasi untuk bahan aktif pestisida yang banyak digunakan di Indonesia. 


\section{DAFTAR PUSTAKA.}

1. ABDUL QUDDUS, Pesticides in Aquatic Environments, Plenum Press, New York and London.

2. EDWARDS C.A. 1973 Environmental Pollution by Pesticides, Plenum Press, London and New York.

3. EXNER H.J., 1982, Detoxication of Hazardous Waste, Ann Arbor Science, Michigan.

4. FREED, V.H., 1975, Environmental Dynamics of Pesticides Plenum Press, New York.

5. HILL, I.R., 1978, Pesticide Microbiology, Academic Press, London, New York, San Francisco.

6. KRUGER, F.R., 1984, Treatment and Disposal of Pesticide Waste America Chemical Society, Washington D.C.

7. SITTIG, M, 1980, Pesticide Manufacturing and Toxic Materials Control Encyclopedia, Noyes Data Corporation Park Ridge, New Jersey, U.S.A. 